\title{
Candida asparagi sp. nov., Candida diospyri sp. nov. and Candida qinlingensis sp. nov., novel anamorphic, ascomycetous yeast species
}

\author{
Hui-Zhong Lu, Jian-Hua Jia, Oi-Ming Wang and Feng-Yan Bai \\ Systematic Mycology and Lichenology Laboratory, Institute of Microbiology, Chinese Academy \\ of Sciences, Beijing 100080, China
}

Correspondence

Feng-Yan Bai

baify@sun.im.ac.cn

\begin{abstract}
Among ascomycetous yeasts that were isolated from several nature reserve areas in China, three anamorphic strains isolated from soil $\left(Q L 5-5^{\top}\right)$ and fruit $\left(Q L 21-2^{\top}\right.$ and SN 15-1 $\left.1^{\top}\right)$ were revealed, by conventional characterization and molecular phylogenetic analysis based on internal transcribed spacer and large subunit (26S) rRNA gene D1/D2 region sequencing, to represent three novel species in the genus Candida. Candida qinlingensis sp. nov. (type strain, $Q L 5-5^{\top}=A S$ $2.2524^{\top}=$ CBS $9768^{\top}$ ) was related closely to a teleomorphic species, Williopsis pratensis. The close relatives of Candida diospyri sp. nov. (type strain, QL $21-2^{\top}=A S 2.2525^{\top}=\mathrm{CBS}^{\top} 769^{\top}$ ) are Candida friedrichii and Candida membranifaciens. Candida asparagi sp. nov. (type strain, SN $15-1^{\top}=$ AS $2.2526^{\top}=$ CBS $9770^{\top}$ ) forms a clade with Candida fructus.
\end{abstract}

In recent years, several hundred ascomycetous yeast strains have been isolated from various substrates that were collected in several nature reserve areas in China. After morphological examination, representative strains were selected for molecular characterization. The data revealed that three taxa, represented by three anamorphic strains that were isolated from the Qinling area, Shanxi Province, and the Shennongjia area, Hubei Province, China, differed from described yeast species in both internal transcribed spacer (ITS) and large subunit (26S) rRNA gene D1/D2 domain sequences. Phenotypic characterization also indicated that the three taxa differed remarkably from their close relatives. Therefore, three novel species are proposed for these strains.

The yeast strains examined were isolated by an enrichment method using acidified malt extract medium (Yarrow, 1998). Strains QL 5-5 ${ }^{\mathrm{T}}$ and QL $21-2^{\mathrm{T}}$ were isolated from soil and the fruit of a persimmon (Diospyros kaki), respectively. These samples were collected from Qinling Nature Reserve, Shanxi Province, China. Strain SN $15-1^{\mathrm{T}}$ was isolated from an Asparagus filicinus fruit that was collected from Shennongjia Nature Reserve, Huber Province, China. The type strains of Candida friedrichii (CBS $4114^{\mathrm{T}}$ ), Candida fructus (CBS $6380^{\mathrm{T}}$ ), Candida membranifaciens (CBS $1952^{\mathrm{T}}$ ), Candida musae (CBS $6381^{\mathrm{T}}$ ) and Williopsis pratensis $\left(\right.$ CBS $6870^{\mathrm{T}}$ ), employed for ITS sequencing, were obtained

Published online ahead of print on 23 January 2004 as DOI 10.1099/ ijs.0.03055-0.

Abbreviation: ITS, internal transcribed spacer.

The GenBank/EMBL/DDBJ accession numbers for the 26S rRNA gene D1/D2 and ITS region sequences determined in this study are AY450916-AY450921 and AY452739-AY452742, respectively. from the Centraalbureau voor Schimmelcultures (CBS), Delft, The Netherlands.

Morphological, physiological and biochemical characteristics were examined according to standard methods that are employed in yeast taxonomy (Yarrow, 1998). Assimilation of nitrogen compounds was investigated on solid media with starved inocula (Nakase \& Suzuki, 1986).

Nuclear DNA was extracted by the method of Makimura et al. (1994). A DNA fragment covering the ITS region (including the $5 \cdot 8 \mathrm{~S}$ rRNA gene) and $26 \mathrm{~S}$ rRNA gene D1/ D2 domain was amplified with the primer pair ITS1 $\left(5^{\prime}-\right.$ GTCGTAACAAGGTTTCCGTAGGTG-3') and NL4 (5'GGTCCGTGTTTCAAGACGG-3'). PCR was performed for 36 cycles with denaturation at $94{ }^{\circ} \mathrm{C}$ for $1 \mathrm{~min}$, annealing at $55^{\circ} \mathrm{C}$ for $1 \mathrm{~min}$ and extension at $72^{\circ} \mathrm{C}$ for $2 \mathrm{~min}$. After purification, PCR products were sequenced directly with the forward primers ITS1 and NL1 (5'-GCATATCAATAAGCGGAGGAAAAG-3') and the reverse primers ITS4 (5'TCCTCCGCTTATTGATATGC-3') and NL4, by using an ABI BigDye Terminator cycle sequencing kit. Electrophoresis was done on an ABI PRISM 377 DNA sequencer.

Sequences were aligned with the program CLUSTAL_X (Thompson et al., 1997). A phylogenetic tree was constructed from evolutionary distance data that were calculated with Kimura's two-parameter model (Kimura, 1980) by using the neighbour-joining method (Saitou \& Nei, 1987). Bootstrap analysis (Felsenstein, 1985) was performed on 1000 random resamplings. Reference sequences were retrieved from GenBank under the accession numbers indicated in the tree. 


\section{Sequence analysis}

Databases of $26 \mathrm{~S}$ rRNA gene D1/D2 sequences are now available for all currently recognized yeast species (Kurtzman \& Robnett, 1997, 1998; Fell et al., 2000), resulting in increasing use of this domain for yeast species identification. Previous studies have shown that strains with $>1 \%$ substitution in the D1/D2 domain usually represent separate species. The ITS region has also been proved to be useful for yeast taxonomy, with a similar amount of intraspecific variation (James et al., 1996; Sugita et al., 1999; Bai et al., 2001, 2002; Scorzetti et al., 2002; Kurtzman \& Robnett, 2003). Combined sequence analysis of the D1/D2 and ITS regions for yeast species identification has been recommended (Scorzetti et al., 2002).

$\mathrm{D} 1 / \mathrm{D} 2$ sequence analysis showed that strain QL $5-5^{\mathrm{T}}$ is related most closely to the ascogenous yeast species W. pratensis (Fig. 1). However, the sequence of strain QL $5-5^{\mathrm{T}}$ differed from that of $W$. pratensis by $2 \cdot 4 \%$ (five substitutions, nine gaps) in the D1/D2 domain. The ITS sequence of strain QL 5-5 ${ }^{\mathrm{T}}$ (GenBank no. AY450917) differed from that of $W$. pratensis (James et al., 1998) by
$10 \cdot 4 \%$ (seven substitutions, eight gaps) and 5.8\% (nine substitutions) in the ITS 1 and ITS 2 regions, respectively.

Strain QL $21-2^{\mathrm{T}}$ forms a clade with $C$. friedrichii and C. membranifaciens (Fig. 1). This strain differed from each of the latter two species by $1.5 \%$ (six substitutions, two gaps) in the D1/D2 domain. The ITS regions of strain QL 21$2^{\mathrm{T}}$ (GenBank no. AY450919) and type strains of C. friedrichii (GenBank no. AY452739) and C. membranifaciens (GenBank no. AY452740) were sequenced and compared further. In this region, the sequence of strain QL $21-2^{\mathrm{T}}$ differed from those of $C$. friedrichii and C. membranifaciens by approximately $10 \%$ (31-33 substitutions, five or six gaps); the latter two species differed from each other by $1.8 \%$ (four substitutions, three gaps).

The close relationship between strain SN $15-1^{\mathrm{T}}$ and C. fructus is depicted in Fig. 1. The D1/D2 region sequence of strain SN $15-1^{\mathrm{T}}$ differed by $2 \cdot 1 \%$ (10 substitutions, one gap) from that of $C$. fructus. The distinction of SN $15-1^{\mathrm{T}}$ was further supported by ITS sequence comparison. The total lengths of ITS 1 and ITS 2 regions of this group of species were only about $170 \mathrm{bp}$. In this region, SN $15-1^{\mathrm{T}}$ (GenBank no.

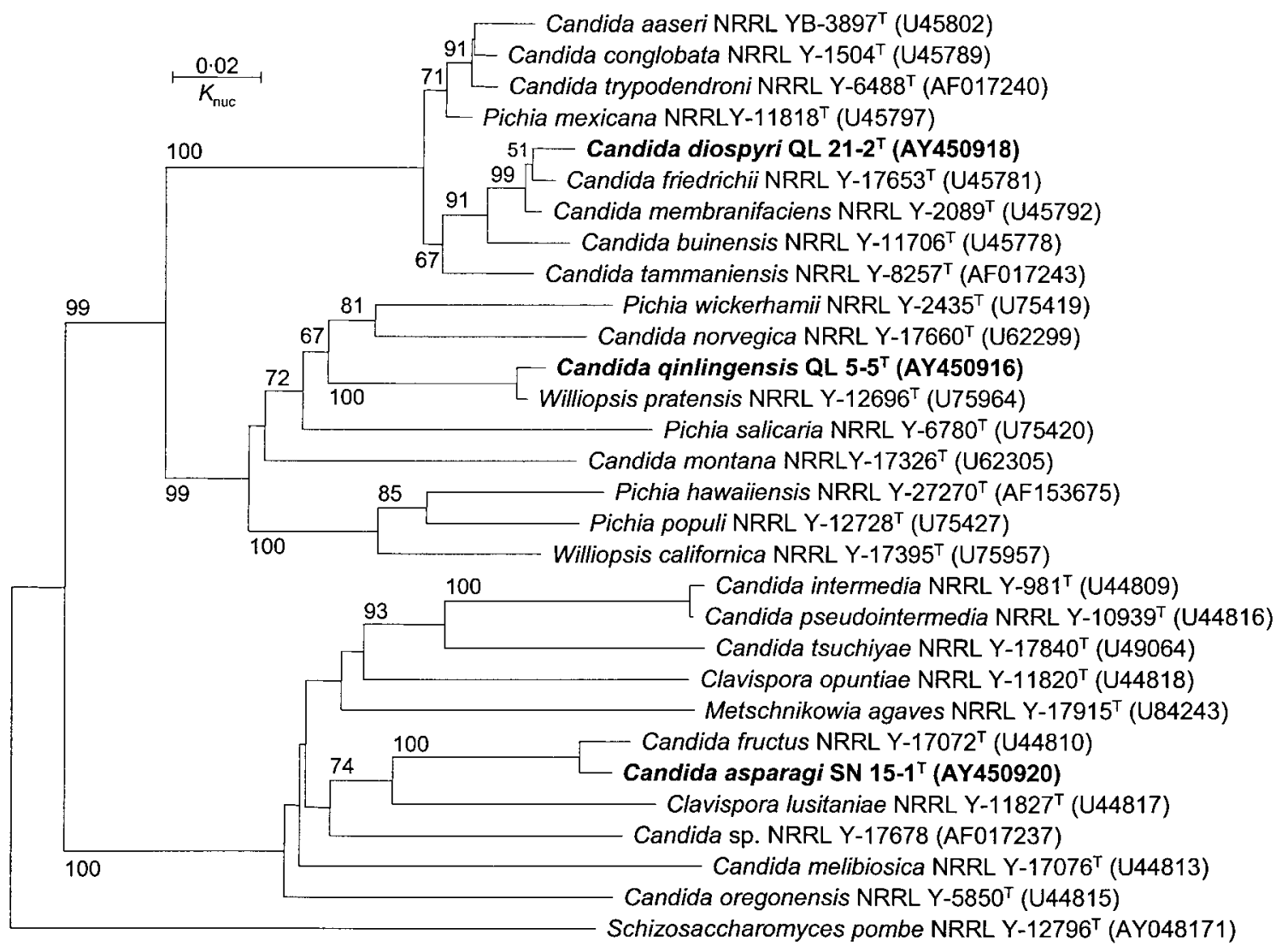

Fig. 1. Phylogenetic tree drawn from neighbour-joining analysis of $26 S$ rRNA gene D1/D2 domain sequences, depicting the relationships of the three novel Candida species with closely related taxa. Bootstrap percentages $>50 \%$ from 1000 bootstrap replicates are shown. Reference sequences were retrieved from GenBank under the accession numbers indicated. 
AY450921) differed from C. fructus (GenBank no. AY452741) by $11 \cdot 4 \%$ (13 substitutions, six gaps).

Kurtzman \& Robnett $(1997,1998)$ predicted that C. musae was a synonym of $C$. fructus, based on observation of their identical D1/D2 sequences. The present study showed that the ITS sequence of C. musae (GenBank no. AY452742) was also identical to that of $C$. fructus, and thus confirmed the conspecificity of these two taxa.

\section{Morphology and physiology}

As strain QL $5-5^{\mathrm{T}}$ was related most closely to the teleomorphic species $W$. pratensis, special efforts have been made to induce its sexual state. Most Williopsis species form asci and ascospores on $5 \%$ malt extract agar at $25^{\circ} \mathrm{C}$ after 1-3 weeks (Kurtzman, 1998a). However, a sexual state was not observed in cultures of QL $5-5^{\mathrm{T}}$ on the same medium or other media, including corn-meal agar and potato dextrose agar. Ascospores of $W$. pratensis were also no longer observed (Kurtzman, 1998a). Likewise, sexual states were not observed in strain QL $21-2^{\mathrm{T}}$ or SN $15-1^{\mathrm{T}}$.

Physiologically, strain QL $5-5^{\mathrm{T}}$ differed remarkably from $W$. pratensis in the fermentation reactions of galactose, sucrose and maltose and in the assimilation reactions of L-sorbose and L-arabinose. Strain QL $21-2^{\mathrm{T}}$ differed from C. friedrichii by its inability to assimilate melibiose, raffinose and galactitol, its ability to assimilate L-rhamnose and D-glucosamine and its higher maximum growth temperature. This strain differed from another closely related species, C. membranifaciens, in the fermentation reactions of sucrose and raffinose and the assimilation reactions of melibiose, raffinose, inulin and galactitol. Strain SN 15-1 ${ }^{\mathrm{T}}$ could be differentiated from its closest relative, C. fructus, by galactose fermentation and galactose, cellobiose, D-arabinose, methyl $\alpha$-D-glucoside and salicin assimilation reactions.

The molecular and physiological comparison made above demonstrated that strains QL 5-5 ${ }^{\mathrm{T}}$, QL $21-2^{\mathrm{T}}$ and SN $15-1^{\mathrm{T}}$ represent three distinct, novel, ascomycetous yeast species. According to the current taxonomy of yeasts, these species can be assigned to the genus Candida Berkhout (Kurtzman, 1998b; Meyer et al., 1998). The names Candida qinlingensis sp. nov., Candida diospyri sp. nov. and Candida asparagi sp. nov. are therefore proposed for these three novel anamorphic species.

\section{Latin diagnosis of Candida qinlingensis Bai et Lu sp. nov.}

In medio liquido $\mathrm{YM}$ post dies 3 ad $25^{\circ} \mathrm{C}$, cellulae globosae $(1 \cdot 8-6 \cdot 0 \mu \mathrm{m})$ vel ellipsoideae $(2 \cdot 0-5 \cdot 0 \times 2 \cdot 5-6 \cdot 5 \mu \mathrm{m})$, cellulae singulae, binae, adhaerentes. per gemmationem multipolarem reproducentes. Post 1 mensem sedimentum formatur. In agaro $\mathrm{YM}$ post 1 mensem ad $25^{\circ} \mathrm{C}$, butyrosa, candida vel cremea, glabra, pauro hebia, margo glabro vel undulato. In agaro farinae Zea mays post dies 7, pseudohyphae nullae. Ascomata nulla. Glucosum fermentatur at non galactosum, sucrosum, maltosum, lactosum nec raffinosum. Glucosum, galactosum, L-sorbosum, sucrosum, maltosum, cellobiosum, trehalosum (lente), D-xylosum (lente), L-arabinosum, ethanolum (lente), glycerolum, D-mannitolum (lente), D-glucitolum (lente), methyl- $\alpha$-D-glucosidum, salicinum, acidum DL-lacticum, acidum succinicum et acidum citricum (infirme) assimilantur at non lactosum, melibiosum, raffinosum, melezitosum, inulinum, amylum solubile, D-arabinosum, D-ribosum, L-rhamnosum, D-glucosaminum, methanolum, erythritolum, ribitolum, galactitolum, inositolum nec hexadecanum. Ammonium sulfatum, ethylaminum, natrum nitrosum, L-lysinum et cadaverinum assimilantur at non kalium nitricum. Ad crescentiam vitaminae externae necessariae sunt. Maxima temperatura crescentiae: $30^{\circ} \mathrm{C}$. Materia amyloidea iodophila non formantur. Diazonium caeruleum B non respondens. Ureum non hydrolysatur. Typus: isolatus ex solis, QL 5-5 ${ }^{\mathrm{T}}$, depositus in collectione China General Microbiological Culture Collection Center, Academia Sinica (AS 2.2524 ${ }^{\mathrm{T}}$ ).

\section{Description of Candida qinlingensis Bai \& Lu sp. nov.}

Candida qinlingensis (qin.ling.en'sis N.L. fem. adj. qinlingensis pertaining to Qinling, the geographical origin of the type strain of the species).

Growth in YM broth: after 3 days at $25^{\circ} \mathrm{C}$, cells are globose $(1 \cdot 8-6 \cdot 0 \mu \mathrm{m})$ to ellipsoidal $(2 \cdot 0-5 \cdot 0 \times 2 \cdot 5-6 \cdot 5 \mu \mathrm{m})$ and occur singly, in pairs or in groups (Fig. 2a). Budding is multilateral. After 1 month at $25^{\circ} \mathrm{C}$, sediment is present. Growth on YM agar: after 1 month at $25^{\circ} \mathrm{C}$, the streak culture is butyrous, white to cream, smooth and somewhat dull, with an entire to undulating margin. Dalmau plate culture on corn-meal agar: after 7 days at $25^{\circ} \mathrm{C}$, pseudohyphae and ascospores are not formed. Glucose is fermented; galactose, sucrose, maltose, lactose and raffinose are not. Glucose, galactose, L-sorbose, sucrose, maltose, cellobiose, trehalose (delayed), D-xylose (delayed), L-arabinose, ethanol (delayed), glycerol, D-mannitol (delayed), D-glucitol (delayed), methyl $\alpha$-D-glucoside, salicin, DL-lactic acid, succinic acid and citric acid (weak) are assimilated; lactose, melibiose, raffinose, melezitose, inulin, soluble starch, D-arabinose, D-ribose, L-rhamnose, D-glucosamine, methanol, erythritol, ribitol, galactitol, inositol and hexadecane are not. Ammonium sulfate, ethylamine hydrochloride, sodium nitrite, L-lysine and cadaverine dihydrochloride are assimilated; potassium nitrate is not. Growth in vitamin-free medium is negative. Maximum growth temperature is $30^{\circ} \mathrm{C}$. Starch-like compounds are not produced. Urease activity is negative. Diazonium blue B reaction is negative.

The type strain, QL 5-5 $5^{\mathrm{T}}$, was isolated from soil collected in Qinling, Shanxi Province, China, in October, 2002. This strain has been deposited in the China General Microbiological Culture Collection Center (CGMCC), Academia Sinica, Beijing, China, as AS $2.2524^{\mathrm{T}}$ (=CBS $9768^{\mathrm{T}}$ ). 

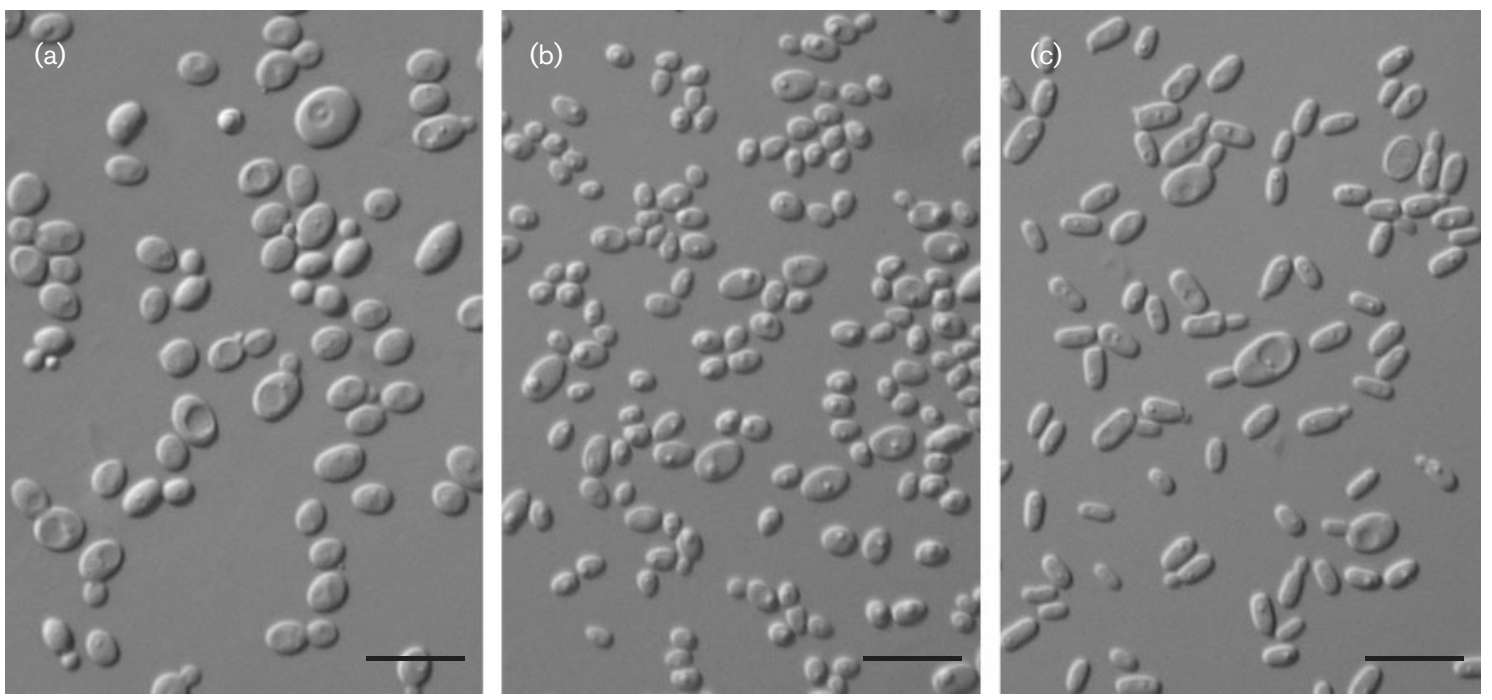

Fig. 2. Vegetative cells of (a) Candida qinlingensis $\mathrm{QL} 5-5^{\top}$, (b) Candida diospyri $\mathrm{QL} 21-2^{\top}$ and (c) Candida asparagi SN $15-1^{\top}$, grown in YM broth for 3 days at $25^{\circ} \mathrm{C}$. Bars, $10 \mu \mathrm{m}$.

\section{Latin diagnosis of Candida diospyri Bai et Lu sp. nov.}

In medio liquido $\mathrm{YM}$ post dies 3 ad $25^{\circ} \mathrm{C}$, cellulae ellipsoideae vel elongatae $(1 \cdot 8-5 \cdot 0 \times 2 \cdot 0-5 \cdot 5 \mu \mathrm{m})$, cellulae singulae, binae et aggregatae. per gemmationem multipolarem reproducentes. Post 1 mensem sedimentum formatur. In agaro YM post 1 mensem ad $25^{\circ} \mathrm{C}$, butyrosa, candida vel cremea, glabra, pauro hebia, margine glabra. In agaro farinae Zea mays post dies 7, pseudohyphae nullae. Ascomata nulla. Glucosum et galactosum fermentatur at non sucrosum, maltosum, lactosum nec raffinosum. Glucosum, galactosum, L-sorbosum, sucrosum, maltosum, cellobiosum, trehalosum, melezitosum, D-xylosum, L-arabinosum, D-arabinosum, D-ribosum, L-rhamnosum, D-glucosaminum (infirme), ethanolum, glycerolum, erythritolum, ribitolum, D-mannitolum, D-glucitolum, methyl- $\alpha-\mathrm{D}-$ glucosidum, salicinum, acidum succinicum, acidum citricum (lente) et hexadecanum assimilantur at non lactosum, melibiosum, raffinosum, inulinum, amylum solubile, methanolum, galactitolum, acidum DL-lacticum nec inositolum. Ammonium sulfatum, ethylaminum, L-lysinum et cadaverinum assimilantur at non kalium nitricum nec natrum nitrosum. Vitaminae externae ad crescentiam necessariae sunt. Maxima temperatura crescentiae: $35^{\circ} \mathrm{C}$. Materia amyloidea iodophila non formantur. Diazonium caeruleum B non respondens. Ureum non hydrolysatur. Typus: isolatus ex fructu Diospyros kaki, QL 21-2 , depositus in collectione China General Microbiological Culture Collection Center, Academia Sinica (AS 2.2525 ).

\section{Description of Candida diospyri Bai \& Lu sp. nov.}

Candida diospyri (di.os'py.ri. N.L. gen. n. diospyri of Diospyros, referring to the genus name of Diospyros kaki, the source of the type strain of the species).
Growth in YM broth: after 3 days at $25^{\circ} \mathrm{C}$, cells are ellipsoidal to elongate $(1 \cdot 8-5 \cdot 0 \times 2 \cdot 0-5 \cdot 5 \mu \mathrm{m})$ and occur singly, in pairs or in groups (Fig. 2b). Budding is multilateral. After 1 month at $25^{\circ} \mathrm{C}$, sediment is present. Growth on YM agar medium: after 1 month at $25^{\circ} \mathrm{C}$, the streak culture is butyrous, white to cream, smooth and somewhat dull, with an entire margin. Dalmau plate culture on cornmeal agar: after 7 days at $25^{\circ} \mathrm{C}$, pseudohyphae are not formed. Ascospores are not formed. Glucose and galactose are fermented; sucrose, maltose, lactose and raffinose are not fermented. Glucose, galactose, L-sorbose, sucrose, maltose, cellobiose, trehalose, melezitose, D-xylose, L-arabinose, D-arabinose, D-ribose, L-rhamnose, D-glucosamine (weak), ethanol, glycerol, erythritol, ribitol, D-mannitol, D-glucitol, methyl $\alpha$-D-glucoside, salicin, succinic acid, citric acid (delayed) and hexadecane are assimilated; lactose, melibiose, raffinose, inulin, soluble starch, methanol, galactitol, DL-lactic acid and inositol are not. Ammonium sulfate, Llysine, ethylamine hydrochloride and cadaverine dihydrochloride are assimilated. Potassium nitrate and sodium nitrite are not assimilated. Growth in vitamin-free medium is negative. Maximum growth temperature is $35^{\circ} \mathrm{C}$. Starchlike compounds are not produced. Urease activity is negative. Diazonium blue B reaction is negative.

The type strain, QL 21-2 ${ }^{\mathrm{T}}$, was isolated from Diospyros kaki fruit collected in Qinling, Shanxi Province, China, in October 2002. This strain has been deposited in the CGMCC, Academia Sinica, Beijing, China, as AS $2.2525^{\mathrm{T}}$ $\left(=\operatorname{CBS} 9769^{\mathrm{T}}\right)$.

\section{Latin diagnosis of Candida asparagi Bai et Lu sp. nov.}

In medio liquido $\mathrm{YM}$ post dies 3 ad $25^{\circ} \mathrm{C}$, cellulae ellipsoideae vel elongatae $(1 \cdot 2-4 \cdot 5 \times 1 \cdot 8-5 \cdot 5 \mu \mathrm{m})$, cellulae singulae, 
binae et adhaerentes. Per gemmationem multipolarem reproducentes. Post 1 mensem sedimentum formatur. In agaro YM post 1 mensem ad $25^{\circ} \mathrm{C}$, butyrosa, cremea, infimoconvexa, seminitida, margo glabro vel undulato. In agaro farinae Zea mays post dies 7, pseudohyphae nullae. Ascomata nulla. Glucosum et galactosum fermentatur at non sucrosum, maltosum, lactosum nec raffinosum. Glucosum, galactosum, L-sorbosum, sucrosum, maltosum, cellobiosum, trehalosum, melezitosum, D-xylosum, D-arabinosum (infirme), D-ribosum (infirme), D-glucosaminum (lente), ethanolum (lente), glycerolum, ribitolum, D-mannitolum, D-glucitolum, methyl $\alpha-$ D-glucosidum (lente), salicinum (lente), acidum succinicum, acidum citricum (infirme) et hexadecanum (infirme) assimilantur at non lactosum, melibiosum, raffinosum, inulinum, amylum solubile, L-arabinosum, L-rhamnosum, methanolum, erythritolum, galactitolum, acidum DL-lacticum nec inositolum. Ammonium sulfatum, ethylaminum, L-lysinum et cadaverinum assimilantur at non kalium nitricum nec natrum nitrosum. Ad crescentiam vitaminae externae necessariae sunt. Maxima temperatura crescentiae: $33^{\circ} \mathrm{C}$. Materia amyloidea iodophila non formantur. Diazonium caeruleum B non respondens. Ureum non hydrolysatur. Typus: isolatus ex fructu Asparagus filicinus, SN 15-1 ${ }^{\mathrm{T}}$, depositus in collectione China General Microbiological Culture Collection Center, Academia Sinica (AS 2.2526 ${ }^{\mathrm{T}}$ ).

\section{Description of Candida asparagi Bai et Lu sp. nov.}

Candida asparagi (as.pa'ra.gi. N.L. gen. n. asparagi of Asparagus, referring to the genus name of Asparagus filicinus, the source of the type strain of the species).

Growth in YM medium: after 3 days at $25^{\circ} \mathrm{C}$, cells are ellipsoidal to elongate $(1 \cdot 2-4 \cdot 5 \times 1 \cdot 8-5 \cdot 5 \mu \mathrm{m})$ and occur singly, in pairs or in groups (Fig. 2c). Budding is multilateral. After 1 month at $25^{\circ} \mathrm{C}$, sediment is present. Growth on YM agar medium: after 1 month at $25^{\circ} \mathrm{C}$, the streak culture is butyrous, cream and semi-glossy, with an entire to slightly undulating margin. Dalmau plate culture on cornmeal agar: after 7 days at $25^{\circ} \mathrm{C}$, pseudohyphae are not formed. Ascospores are not formed. Glucose and galactose are fermented; sucrose, maltose, lactose and raffinose are not fermented. Glucose, galactose, L-sorbose, sucrose, maltose, cellobiose, trehalose, melezitose, D-xylose, D-arabinose (weak), D-ribose (weak), D-glucosamine (delayed), ethanol (delayed), glycerol, ribitol, D-mannitol, D-glucitol, methyl $\alpha$-D-glucoside (delayed), salicin (delayed), succinic acid, citric acid (weak) and hexadecane (weak) are assimilated; lactose, melibiose, raffinose, inulin, soluble starch, L-arabinose, L-rhamnose, methanol, erythritol, galactitol, DL-lactic acid and inositol are not. Ammonium sulfate, ethylamine hydrochloride, L-lysine and cadaverine dihydrochloride are assimilated; potassium nitrate and sodium nitrite are not. Growth in vitamin-free medium is negative. Maximum growth temperature is $33^{\circ} \mathrm{C}$. Starch-like compounds are not produced. Diazonium blue $\mathrm{B}$ reaction is negative. Urease activity is negative.
The type strain, SN 15-1 ${ }^{\mathrm{T}}$, was isolated from Asparagus filicinus fruit collected in Shennongiia, Hubei Province, China, in October 2002. This strain has been deposited in the CGMCC, Academia Sinica, Beijing, China, as AS $2.2526^{\mathrm{T}}\left(=\mathrm{CBS} 9770^{\mathrm{T}}\right)$.

\section{Acknowledgements}

This study was supported by grants no. KSCX2-SW-101C from the Chinese Academy of Sciences and no. 2001AA227131 of the ' 863 program' from the Ministry of Science and Technology, China.

\section{References}

Bai, F.-Y., Takashima, M. \& Nakase, T. (2001). Phylogenetic analysis of strains originally assigned to Bullera variabilis: descriptions of Bullera pseudohuiaensis sp. nov., Bullera komagatae sp. nov. and Bullera pseudoschimicola sp. nov. Int J Syst Evol Microbiol 51, 2177-2187.

Bai, F.-Y., Zhao, J.-H., Takashima, M., Jia, J.-H., Boekhout, T. \& Nakase, T. (2002). Reclassification of the Sporobolomyces roseus and Sporidiobolus pararoseus complexes, with the description of Sporobolomyces phaffii sp. nov. Int J Syst Evol Microbiol 52, 2309-2314.

Fell, J. W., Boekhout, T., Fonseca, A., Scorzetti, G. \& StatzellTallman, A. (2000). Biodiversity and systematics of basidiomycetous yeasts as determined by large-subunit rDNA D1/D2 domain sequence analysis. Int J Syst Evol Microbiol 50, 1351-1371.

Felsenstein, J. (1985). Confidence limits on phylogenies: an approach using the bootstrap. Evolution 39, 783-791.

James, S. A., Collins, M. D. \& Roberts, I. N. (1996). Use of an rRNA internal transcribed spacer region to distinguish phylogenetically closely related species of the genera Zygosaccharomyces and Torulaspora. Int J Syst Bacteriol 46, 189-194.

James, S. A., Roberts, I. N. \& Collins, M. D. (1998). Phylogenetic heterogeneity of the genus Williopsis as revealed by $18 \mathrm{~S}$ rRNA gene sequence. Int J Syst Bacteriol 48, 591-596.

Kimura, M. (1980). A simple method for estimating evolutionary rates of base substitutions through comparative studies of nucleotide sequences. J Mol Evol 16, 111-120.

Kurtzman, C. P. (1998a). Williopsis Zender. In The Yeasts, a Taxonomic Study, 4th edn, pp. 413-419. Edited by C. P. Kurtzman \& J. W. Fell. Amsterdam: Elsevier.

Kurtzman, C. P. (1998b). Discussion of teleomorphic and anamorphic ascomycetous yeasts and a key to genera. In The Yeasts, a Taxonomic Study, 4th edn, pp. 111-121. Edited by C. P. Kurtzman \& J. W. Fell. Amsterdam: Elsevier.

Kurtzman, C. P. \& Robnett, C. J. (1997). Identification of clinically important ascomycetous yeasts based on nucleotide divergence in the $5^{\prime}$ end of the large-subunit (26S) ribosomal DNA gene. J Clin Microbiol 35, 1216-1223.

Kurtzman, C. P. \& Robnett, C. J. (1998). Identification and phylogeny of ascomycetous yeasts from analysis of nuclear large subunit (26S) ribosomal DNA partial sequences. Antonie van Leeuwenhoek 73, 331-371.

Kurtzman, C. P. \& Robnett, C. J. (2003). Phylogenetic relationships among yeasts of the 'Saccharomyces complex' determined from multigene sequence analyses. FEMS Yeast Res 3, 417-432.

Makimura, K., Murayama, S. Y. \& Yamaguchi, H. (1994). Detection of a wide range of medically important fungi by the polymerase chain reaction. J Med Microbiol 40, 358-364. 
Meyer, S. A., Payne, R. W. \& Yarrow, D. (1998). Candida Berkhout. In The Yeasts, a Taxonomic Study, 4th edn, pp. 454-573. Edited by C. P. Kurtzman \& J. W. Fell. Amsterdam: Elsevier.

Nakase, T. \& Suzuki, M. (1986). Bullera megalospora, a new species of yeast forming large ballistospores isolated from dead leaves of Oryza sativa, Miscanthus sinensis, and Sasa sp. in Japan. J Gen Appl Microbiol 32, 225-240.

Saitou, N. \& Nei, M. (1987). The neighbor-joining method: a new method for reconstructing phylogenetic trees. Mol Biol Evol 4, 406-425.

Scorzetti, G., Fell, J. W., Fonseca, A. \& Statzell-Tallman, A. (2002). Systematics of basidiomycetous yeasts: a comparison of large subunit
D1/D2 and internal transcribed spacer rDNA regions. FEMS Yeast Res 2, 495-517.

Sugita, T., Nishikawa, A., Ikeda, R. \& Shinoda, T. (1999). Identification of medically relevant Trichosporon species based on sequences of internal transcribed spacer regions and construction of a database for Trichosporon identification. J Clin Microbiol 37, 1985-1993.

Thompson, J. D., Gibson, T. J., Plewniak, F., Jeanmougin, F. \& Higgins, D. G. (1997). The CLUSTAL_X windows interface: flexible strategies for multiple sequence alignment aided by quality analysis tools. Nucleic Acids Res 25, 4876-4882.

Yarrow, D. (1998). Methods for the isolation, maintenance and identification of yeasts. In The Yeasts, a Taxonomic Study, 4th edn, pp. 77100. Edited by C. P. Kurtzman \& J. W. Fell. Amsterdam: Elsevier. 